\title{
Composition of ilmenite and provenance of zircon in northern Brazil
}

\author{
Christian Knudsen, Tonny B. Thomsen, Feiko Kalsbeek, Jeppe A. Kristensen, Helenice Vital and \\ Roger K. McLimans
}

The mineral ilmenite $\left(\mathrm{FeTiO}_{3}\right)$ is an important component of heavy-mineral placer deposits and constitutes the largest volume of valuable mineral in such deposits. The minerals zircon $\left(\mathrm{ZrSiO}_{4}\right)$ and rutile $\left(\mathrm{TiO}_{2}\right)$, which occur in lower concentrations than ilmenite in the deposits, have a greater value per ton - c. 1100 and $900 \$ /$ ton respectively - compared to ilmenite that ranges from 100 to $200 \$$ /ton depending on its composition. Other minerals such as staurolite, sillimanite, amphibole and garnet are generally also present in placer deposits, but are of minor or no commercial value and, e.g. amphibole needs to be separated from the valuable heavy minerals which adds to the production cost.

Ilmenite is more valuable as a raw material in titanium dioxide manufacture if the titanium content is enhanced by natural leaching of the iron component. When exploring for potentially economic heavy-mineral placer deposits, both the variation in composition and distribution of ilmenite are of interest. Accordingly, it is also important to understand not only the concentration of heavy minerals in the ground but also the abundance and composition of the individual minerals.

The source (provenance), route and mechanism of transport from source to potential reservoir sandstones are of interest when attempting to understand petroleum systems in sedimentary basins. Heavy minerals in reservoir sandstones contain a wealth of information about their formation that characterises their source. Thus a database with the characteristics of possible sediment sources is a key tool to investigate the distribution, composition and other characteristics

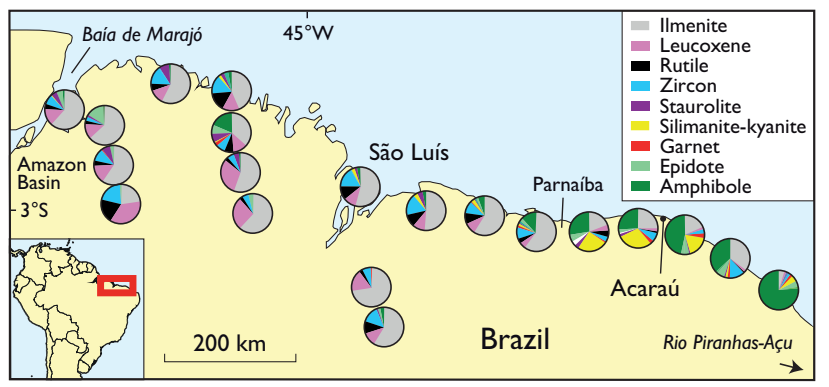

Fig. 1. Modal composition of the heavy-mineral fraction in sand samples from northern Brazil. of the heavy minerals in a given area. Both heavy-mineral exploration and locating offshore petroleum reservoir sand sources are relevant in northern Brazil. In June 2011, the Geological Survey of Denmark and Greenland in cooperation with Universidade Federal do Rio Grande do Norte, Natal, RN, Brazil set up a project to sample and analyse in situ Cretaceous sandstones, sands in river beds and sands from the coastal sediments. The results were entered into a database of heavy-mineral compositions and properties. The variation in the distribution of the heavy minerals as well as their composition were determined for 34 samples from northern Brazil using computer-controlled scanning electron microscopy (CCSEM; Keulen et al. 2012). U-Pb ages of detrital zircons were determined by laser ablation inductively coupled plasma mass spectrometry (for analytical procedures see Frei et al. 2006). Four samples for the U-Pb age determinations came from Cretaceous sandstones, two from river beds and two from beaches.

\section{Alteration of the heavy minerals}

When subjected to alteration in the sedimentary environment, heavy minerals react differently depending on the local physical and chemical conditions. In hot and humid conditions minerals such as olivine, pyroxene, amphibole

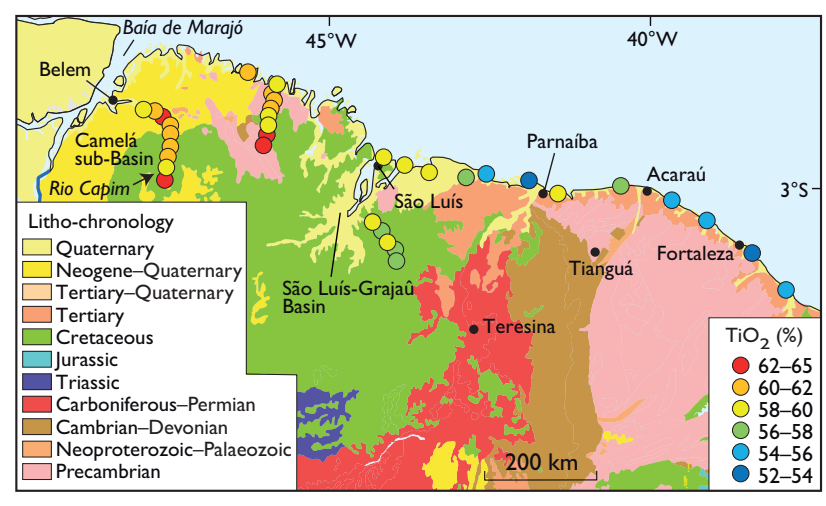

Fig. 2. Average composition of ilmenite and altered ilmenite in samples from beaches, from river beds and from outcrop of Cretaceous sandstone. For location see Fig. 1. 

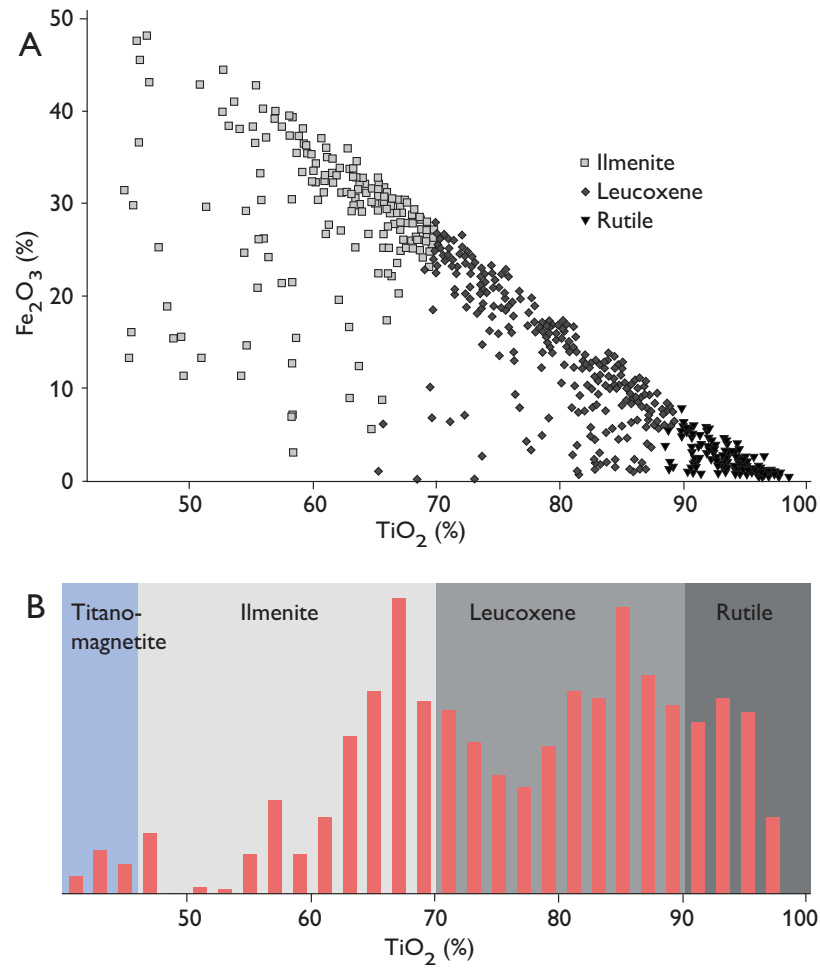

Fig. 3. CCSEM analysis of titanium minerals from a Cretaceous outcrop along Rio Capim (sample GGU 538118). A: The distribution of $\mathrm{TiO}_{2}$ versus $\mathrm{Fe}_{2} \mathrm{O}_{3}$ in the ilmenite, leucoxene and rutile show an inverse relationship between these two components, where $\mathrm{Fe}_{2} \mathrm{O}_{3}$ decreases with increasing $\mathrm{TiO}_{2}-$ and with the degree of weathering. $\mathbf{B}$ : Histogram showing the content of $\mathrm{TiO}_{2}$ in the titanium mineral grains.

and epidote are unstable and gradually disappear from the heavy-mineral assemblage (Morton \& Hallsworth 1999). The heavy-mineral assemblages in the five easternmost beach sand samples from the northern Brazilian coast (Fig. 1) all contain abundant amphibole. The source of those heavy minerals is the Precambrian basement in the hinterland (pink, Fig. 2). A similar, diverse, heavy-mineral assemblage is described by da Silva \& Vital (2000) in samples from the Rio Piranhas-Açu, north-eastern Brazil. The low degree of alteration of the heavy minerals is probably due to the climate which is arid in this part of Brazil. The heavy-mineral assemblages of the five eastern samples change westwards with increasing contents of alumina-silicates such as staurolite, sillimanite and kyanite; minerals which must be abundant in the hinterland, and which can fingerprint the sediment source for the eastern samples. To the west of Parnaiba (Fig. 1), the heavy-mineral assemblages are dominated by ilmenite, leucoxene, rutile, staurolite and zircon, which are very stable minerals (Morton \& Hallsworth 1999). The precipitation, humidity and temperature increase towards the west and towards the Amazon Basin. This may account for the min-

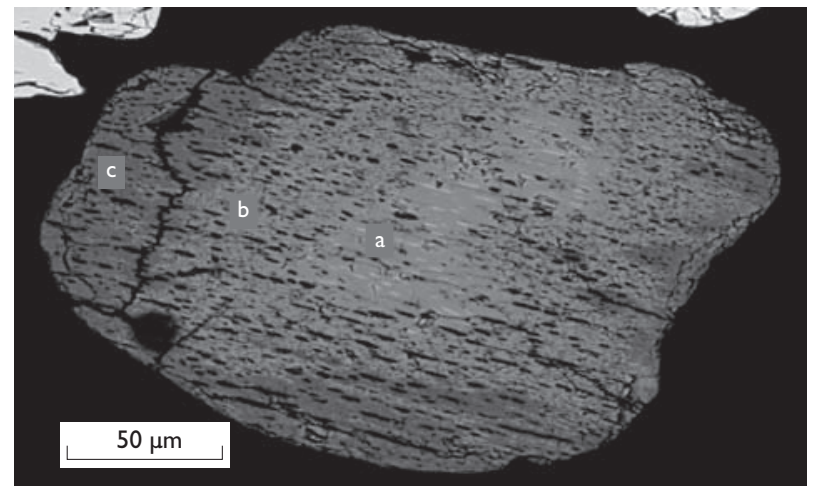

Fig. 4. Scanning electron microscope (SEM) backscatter image of an ilmenite grain leached from the rim. In the light grey central part of the grain (a), the ilmenite is un-leached with preserved white hematite lamellae. Surrounding the un-leached core there is a zone (b), where the hematite is leached away forming pores (black) and where the ilmenite shows partial leaching (dark grey patches). In the grey rim (c), the ilmenite is highly leached and almost all iron is removed leading to the formation of leucoxene.

eralogical change indicative of intense alteration where even fairly stable heavy minerals like garnet have disappeared.

The Cretaceous sandstone in the interior of northern Brazil is altered by intense kaolinisation. Mendes \& Truckenbrodt (2009) describe a mature heavy-mineral assemblage from Albian sandstones (Itapecuru Group) in the São LuísGrajaû Basin and Góes et al. (2007) described similar assemblages from the Campanian-Maastrichtian (Ipixuna Formation) in the Camelá sub-basin to the west. Only robust heavy minerals such as ilmenite, zircon, rutile and staurolite are present in the Cretaceous samples inland south of São Luís and Baia de Marajá (Fig. 1) whereas less stable heavy minerals are lacking. The higher degree of alteration found in the heavy-mineral assemblage in the coastal beach samples in the western section of the coast could accordingly also be an effect of re-deposition of Cretaceous sandstones from the hinterland.

\section{IImenite composition}

The titanium content of ilmenite changes when it is subjected to chemical weathering; iron is leached and the relative content of titanium increases (Fig. 3A). Ultimately the mineral leucoxene, which mainly consists of $\mathrm{TiO}_{2}$, is formed (Bailey et al. 1956). A gradual increase of $\mathrm{TiO}_{2}$ in ilmenite in beach sand is evidenced towards the west (Fig. 2). As discussed above that may be an effect of increasing humidity, but it may also be caused by an influx of reworked sediment from altered Cretaceous sandstones in the hinterland. The $\mathrm{TiO}_{2}$ content of ilmenite in the Albian sandstones (Itape- 




Fig. 5. U/Pb age distributions of detrital zircons from samples from northern Brazil. The two green stars to the east represent sandstone samples from the Albian Itapecuru Group and the two green stars to the west represent sandstone samples from the Campanian-Maastrichtian Ipixuna Formation. For location see Fig. 1.

curu Group; eastern line of samples in Fig. 2) is high and the $\mathrm{TiO}_{2}$ content is even higher in the Campanian-Maastrichtian (Ipixuna Formation) located in the more humid climate to the west.

The heavy-mineral assemblage from a Cretaceous outcrop along Rio Capim is dominated by ilmenite. Figure 3B shows that the content of $\mathrm{TiO}_{2}$ in the titanium minerals has a bimodal distribution with almost no unaltered ilmenite $\left(50 \% \mathrm{TiO}_{2}\right)$. The bimodal distribution may indicate that the weathering is a two stage process.

An example of chemical weathering of an ilmenite grain is shown in Fig. 4. The grain has a central core that is largely unaltered with hematite lamellae preserved, an intermediate zone where the hematite is leached away giving rise to porosity, and an outer margin that is completely transformed to leucoxene.

\section{Zircon provenance}

The crystalline basement complexes underlying the investigated sedimentary rocks in the eastern part of the area is the Borborema Province (de Almeida et al. 1981) that is composed of a complex assemblage of Palaeoproterozoic granitoid and metasedimentary gneisses, locally with outcrops of Archaean rocks and with numerous plutons of Neoproterozoic granite. Neoproterozoic sedimentary successions are also present. Palaeoproterozoic granitoid rocks are the most common, forming some $70 \%$ of the basement complex. The São Luís Craton in the west is dominated by the Trans Amazonian Orogeny with ages ranging from 2000 to $2200 \mathrm{Ma}$ (Klein et al. 2005).

The U-Pb age distribution patterns for eight samples from north-eastern Brazil (Fig. 5) show the ages of zircon sand grains. Four of these are from Cretaceous sandstone, two are riverbed sand, and two are coastal sand. The age distributions (Fig. 5) are complex. The largest component in all samples is formed by Palaeo- 
proterozoic zircons, 1800-2300 Ma, comprising 50-70\% of the zircon populations. Archaean zircons (2500-3500 Ma) constitute $10-25 \%$ of the population and Neoproterozoic zircons $(500-700 \mathrm{Ma})$ constitute $10-20 \%$ of the population. Only some $15 \%$ of the zircons have ages outside these age groups. There are no obvious differences in age for the zircon populations in the Cretaceous sediments, the riverbed sands and the coastal sands.

Zircons with ages in the range 2000 to $2200 \mathrm{Ma}$, equivalent to the Trans-Amazonian Orogeny (green columns on Fig. 5) are common in all samples, in good accordance with observations made by Klein et al. (2005). The content of zircons in the age range 1800-2000 varies considerably. Neoproterozoic ages (blue columns on Fig. 5) equivalent to Braziliano or Pan-African Orogeny are less frequent in the analysed sands as compared to what is previously described from the Borborema Province (Nascimento et al. 2007).

\section{Discussion and conclusion}

The heavy-mineral assemblages in the east are less mature than assemblages in the west. That may reflect a lower degree of alteration of the heavy minerals caused by a drier climate. In the hot and humid area to the west in the Amazon Basin, the heavy-mineral assemblages are very mature reflecting the intense chemical attack and removal of heavy minerals such as pyroxene, amphibole and garnet. Indications of more intense chemical alteration of the heavy minerals are also seen from the composition of ilmenite that shows decreasing iron content and accordingly increasing content of $\mathrm{TiO}_{2}$ towards the west. Cretaceous sandstones in the area are kaolinised and the heavy minerals are also strongly altered, most intensely in the hot and humid area in the Amazon Basin. The high degree of alteration found in river and beach sediments in the western area could also be caused by reworking of previously altered Cretaceous sandstones.

Apparently, nearly all zircons in the investigated sediments may originate from the underlying crystalline basement, suggesting mainly local source areas. The zircon-age spectra are fairly uniform suggesting either that the geology in the source area is rather uniform or that the zircons were homogenised in the sedimentary environment and that the sand in the rivers and on the beach at least partly represent reworked Cretaceous sandstones.

\section{Acknowledgements}

DuPont Titanium Technologies, Wilmington, Delaware, USA is thanked for financial support. Francisco Canindé and Miguel Borges from Universidade Federal do Rio Grande do Norte, Natal, RN, Brazil are thanked for help during the fieldwork.

\section{References}

Bailey, S.W., Cameron, E.N., Spedden, H.R. \& Weege, R.J. 1956: The alteration of ilmenite in beach sands. Economic Geology 51, 263-279.

da Silva, M.G. \& Vital, H. 2000: Provenance of heavy-minerals in the Piranhas-Açu river, northeastern Brazil. Brazilian Journal of Geology 30, 453-456.

de Almeida, F.F.M., Hasui, Y., de Brito Neves, B.B. \& Fuck, R.A. 1981: Brazilian structural provinces: an introduction. Earth Science Reviews 17, 1-29.

Frei, D., Hollis, J.A., Gerdes, A., Harlov, D., Karlsson, C., Vasquez, P., Franz, C., Johansson, L. \& Knudsen, C. 2006: Advanced in situ geochronological and trace element microanalysis by laser ablation techniques. Geological Survey of Denmark and Greenland Survey Bulletin 10, 25-28.

Góes, A.M., Rossetti, D.F. \& Mendes A.C. 2007: Heavy mineral as a tool to refine the stratigraphy of kaolin deposits in the Rio Capim area, northern Brazil. Anais da Academia Brasileira de Ciências 79, 457-471.

Keulen, N.T., Frei, D., Riisager, P. \& Knudsen, C. 2012: Analysis of heavy minerals in sediments by Computer-Controlled Scanning Electron Microscopy (CCSEM): principles and applications. Mineralogical Association of Canada Short Course 42, 167-184.

Klein, E.L., Moura, C.A.V. \& Pinheiro, B.L.S. 2005: Paleoproterozoic crustal evolution of the São Luís Craton, Brazil: evidence from zircon geochronology and Sm-Nd isotopes. Gondwana Research 8, 177-186.

Mendes, A.C. \& Truckenbrodt, W. 2009: Provenance of Albian sandstones (Itapecuru Group), eastern border of São Luís-Grajaú Basin, Maranhão, using heavy mineral analysis and mineral chemistry. Boletim do Museu Paraense Emílio Goeldi, Ciências Naturais 4, 57-74.

Morton, A.C. \& Hallsworth C.R. 1999: Processes controlling the composition of heavy mineral assemblages in sandstones. Sedimentary Geology 124, 3-29.

Nascimento, M.D.S., Góes, A.M. Macambira, M.J.B. \& Brod, J.A. 2007: Provenance of Albian sandstones in the São Luís-Grajaú Basin (northern Brazil) from evidence of $\mathrm{Pb}-\mathrm{Pb}$ zircon ages, mineral chemistry of tourmaline and and palaeocurrent data. Sedimentary Geology 201, $21-42$.

\section{Authors' addresses}

C.K., T.B.T. F.K. \& J.A.K, Geological Survey of Denmark and Greenland, Øster Voldgade 10, DK-1350 Copenhagen K, Denmark; E-mail: ckn@geus.dk H.V., Universidade Federal do Rio Grande do Norte, Natal, RN, Brazil.

R.K.McL DuPont Titanium Technologies, Wilmington, DE, USA. 